\title{
A River That Flows to the Sea: The Marine Biological Diversity MOVEMENT
}

\author{
By Elliott A. Norse
}

\author{
"As many fresh streams meet in one salt sea. . . \\ So may a thousand actions, once afoot, \\ End in one purpose, and be all well borne \\ Without defeat."
}

W E ARE UNIQUE. Although all species affect their environments. Homo sapiens affects more of our planet in more ways to a greater degree than any other species, past or present. But we are also unique in another way that could be our salvation: we can recognize changes harmful to our interests and consciously act to ameliorate or even reverse them. The growing movement to conserve marine biological diversity is humankind's first comprehensive response to the damage we inflict on the world's estuaries. coastal waters, and oceans. Because the marine biodiversity movement is a work-in-progress, to understand where it is going requires an understanding whence it has come.

A movement in human society is like a river system with many beginnings, in which tiny drops of water form and then coalesce within tiny catchments as rivulets that join within progressively larger catchments as small streams, larger creeks. and rivers that ultimately flow to the sea or into basins with no outlet, where they dry up. The analogy goes further: because catchments are of very diverse sizes and because precipitation is diverse among them, some catchments contribute much more to the river's flow and characteristics than others. Some rivers are readily visible at the surface: others flow underground, out of sight. They are connected to springs, aquifers, ponds, or lakes in which waters accumulate and are modified before continuing on their way. Mixing of influents is not

Elliott A. Norse. Marine Conservation Biology Institute. $15806 \mathrm{NE} 47 \mathrm{th}$ Court. Redmond, WA 98052-5208, USA. enorse (a) u.x ashington.edu always immediate and thorough, and they can remain distinct for some time after they have joined (e.g., as the dark. clear Rio Negro and the muddy Rio Solimões waters do after their convergence as the Amazon). One last analogy: from the ground, it is much easier to trace and understand the dynamics of the seaward flow within a catchment, from headwaters to the river mouth. than it is to envision the whole riverine system in all its complexity.

I do not have an historian's synoptic view of the marine biological diversity movement that comes from afar but can provide an on-the-ground perspective of the confluence of ideas that propels this River today. Undoubtedly I will overlook some significant springs or tributaries. an error that should someday be corrected. Although recent trends are encouraging, only time will tell whether the River will flow to the sea strongly enough to affect it significantly, or drain into an arid, landlocked basin and evaporate without a trace.

\section{Biological Diversity}

At present, the marine biodiversity movement is the confluence of two major tributaries: movements focusing on biological diversity and on the sea that came from rivers within separate catchments. A third major tributary-conservation biology - will soon be joining the River, along with others.

The concept of conserving biological diversity at three hicrarchical levels, namely 1 ) genetic diversity among individuals and populations within species, 2) species diversity within higher taxonomic groups or geographic areas, and 3 ) ecosystem diversity among more or less distinct communities of species in their physical settings within
A movement in
human society is like
a river system with
many beginnings, in

which tiny drops of water form and then coalesce within tiny catchments as rivulets that join within progressively larger catchments as small streams, larger creeks, and rivers that ultimately flow to the sea or into basins with no outlet, where they dry up. 
larger areas, has many influents. The origin of this concept has been overlooked in the scientific and policy literature (Harper and Hawksworth, 1994).

The strongest-flowing pure scientific influents of biological diversity were systematics and ecology. Naming and classifying species started long before the birth of sciences as we know them, but systematists in the last two centuries created schemes, based mainly on organisms' morphology and development. that depict the relationships of living things at all taxonomic levels, from kingdoms to subspecies. Ironically, in recent decades, this stream has been drying up-numbers of classical systematists have declined precipitouslyjust when they have made remarkable discoveries of new phyla and dramatically higher estimates of species diversity, when their taxonomic schemes are being tested by molecular geneticists, and when they are making important contributions to conservation.

Ecology's influence on the concept of species diversity was no less substantial, extending back at least to Darwin and Wallace. Starting in the 1950s, ecologists made species diversity a central focus of community ecology by asking questions such as "Why are there so many kinds of animals?" (Hutchinson, 1959), "What determines numbers of species in isolated environments?" (MacArthur and Wilson, 1967), and "How are diversity and stability related?" (Woodwell and Smith, 1969). These questions were being debated fervently by faculty and students when I started graduate school in 1969, but, as in discussions with systematists, their implications for conservation were never a topic.

At that time, species conservation was actively discussed by applied biologists, but their primary focus was producing more deer, ducks. trout, or trees that hunters, fishers, and loggers preferred. Wildlife, fishery, or forestry biologists advocating the study of "nongame" species were lonely voices. Conservation of species diversity owed more to pure than to applied biological sciences.

As David Ehrenfeld (1978) explained in The Arrogance of Humanism, the sources of most human endeavors, including conservation, have been anthropocentric. But the Endangered Species Act (ESA) in 1973 established a far less utilitarian, more biocentric goal for conservation than simply producing more biomass of a few favored species, namely preventing extinctions of species and the elimination of the habitats on which they depend. For the first time, imperiled freshwater mussels and vernal pool annual plants could get some attention heretofore devoted to charismatic megavertebrates and trees. The ESA, however, focused on conserving species as they neared biological extinction, a point by which they are effectively already extinct in a commercial or ecological sense and at which the options for their conservation are already greatly reduced.

As with species conservation, conserving ecosystems had multiple origins, including game preserves in China and Europe that ensured that wealthy royals and nobles had animals to hunt, the 19th century movement to establish national parks to preserve the scenic beauty of the United States. Canada, and New Zealand, and the early 20th century movement in the United States to establish national forests as timber reserves for some future time when the great forests on private lands would be gone. Starting in midcentury. The Nature Conservancy began acquiring land in the United States, first focusing on protecting habitats for endangered species and then on protecting entire biological communities in their natural settings.

Conserving genetic diversity within species might be as old or older than species or ecosystem conservation. People have been conserving favored genes in domesticated plants and animals since agriculture and domestication began, and the modern movement to conserve genetic diversity started by focusing on crop and livestock "germ plasm." The efforts of plant geneticist Nikolai Vavilov and others in the first decades of the 20th Century led to establishment of seed banks for conserving the diversity of wild relatives of crop varieties and "land races." Conserving genes of other wild species was apparently not a concern.

That was my understanding of the status quo at my first staff meeting at the President's Council on Environmental Quality in December 1979, when CEQ Senior Staff Member for Land Use and Wildlife, Malcom Baldwin, mentioned that someone (Norman Myers) had been documenting destruction of tropical forests at rates heretofore unimagined, a finding with grave implications for their species. He asked me to write a new chapter for the next CEQ Annual Report on an unprecedented subject: the status of life on Earth. Knowing no existing term that encompassed all that was being lost, we called it "biological diversity," offering the following definition (Norse and McManus, 1980):

\footnotetext{
Biological diversity includes two related concepts, genetic diversity and ecological diversity. Genetic diversity is the amount of genetic variability among individuals in a single species, whether the species exists as a single interbreeding group or as a number of populations, strains, breeds, races or subspecies. Ecological diversity (species richness) is the number of species in a community of organisms.
}

This definition was clearer than similar terms then in use. In the 1970s, The Nature Conservancy was using the term "natural diversity," and other conservationists and scholars were using "germ plasm", "genetic resources," "genetic diversity." or "wildlife resources" as synonyms for the wealth of species (and, confusingly, the wealth of genes within species). I did not know that the term "biological diversity" had been 
around at least since The Nature of Biological Diversity (Allen, 1963), a book about cell differentiation that had nothing to do with conservation, nor that the term had already been used briefly (although not defined) in a conservation context in a National Research Council report (Russell et al., 1978), by Soulé and Wilcox (1980) and in two publications by Lovejoy (1980a,b): the Foreword of Soule and Wilcox' Conservation Biology and on p. 327 of The Global 2000 Report to the President.

Norman Myers' (1979) landmark The Sinking Ark had emphasized that the worldwide extinction of species was a quantitatively momentous phenomenon spanning a broad range of taxa, rather than a series of isolated tragedies involving a Tasmanian wolf here and a dodo there, something implicit in previous writings on modern extinctions. The realization that biological diversity was being lost on a massive scale at several hierarchical levels (not only species) affected conservation policy and politics rapidly. By 1981 (the inaugural year of the Reagan Administration), it was the focus of the State Department/Agency for International Development's Strategy Conference on Biological Diversity (U.S. Department of State, 1982), the first conference addressing the loss of biological diversity per se. Maintaining biological diversity per se first became the explicit goal of U.S. legislation in a section of the Foreign Assistance Act of 1983 and was incorporated into U.S. foreign policy not long after (U.S. Agency for International Development, 1985).

Paul Ehrlich pointed out an important weakness in the CEQ biological diversity chapter: that it shortchanged biological communities in their physical settings and the services they perform, something I remedied in subsequent writings. The three-level definition of biological diversity widely used now first appeared in Norse et al. (1986). The term was contracted to "biodiversity" the same year at the National Forum on BioDiversity and in the resulting symposium volume (Wilson, 1988). Wilson's book and the study by Congress' Office of Technology Assessment (1987) dramatically increased attention to biological diversity, both domestically and internationally, leading to myriad efforts. One of the most prominent is the global Convention on Biological Diversity, a pool swollen by a flood of concern about about biodiversity loss and distribution of economic benefits from biotechnologies back to the countries whence the biota originated. In preparation for the Convention, World Resources Institute and its partner institutions (1992) assembled the first Global Biodiversity Strategy. The Convention was opened for signature at the UN Conference on Environment and Development in Rio de Janeiro in 1992. and is now being implemented, most recently at its sec- ond Conference of the Parties in Jakarta, Indonesia in November, 1995.

Early on, some people wondered whether biological diversity was merely the newest "buzzword" for what people had been working to conserve for years under some other name. But the concept of biological diversity was a real advance in conservation because:

- it is hierarchical, dealing with loss of diversity at different levels of biological organization:

- it articulates a goal much broader than conserving game, fishery, and timber species or species that are on the verge of disappearing, namely conserving the functional integrity of populations, species, and ecosystems; and

- it brings together previously disparate and politically less powerful movements that focused on conserving genes, species, and ecosystems.

But until recently, this conservation river flowed mainly through terrestrial ecosystems, particularly rainforests, which are both gravely imperiled and have the highest species diversity of any terrestrial ecosystems. There was much less attention given to biological diversity conservation in other imperiled ecosystems, including temperate forests. mediterranean shrublands, tropical floodplain rivers. African rift lakes, and a realm vastly larger than the terrestrial and freshwater realms combined, one with very high biological diversity: the sea. For example, only a few pages (Norse, 1992) of the Global Biodiversity Strategy focused on the marine realm.

\section{Marine Science and Conservation}

As on land, both pure and applied sciences provided the basis for understanding marine biological diversity. but the effort devoted to its conservation has been even smaller. For example, benthic ecology has focused far more on how natural factors influence the composition of seabed communities than how they are affected by widespread anthropogenic disturbances, such as bottom trawling. A few marine disciplines, most notably sea turtle biology, marine mammalogy, and seabird biology, have given stronger emphasis to identifying populations at risk than most. The main focus of marine fishery biology has been maximizing the sustainable yield of fish and shellfish biomass, a utilitarian conservation goal largely unaffected by the early years of the biological diversity movement.

There were portents of a marine biodiversity focus in the years before the concept of biological diversity first appeared, including efforts to prevent the disappearance of great whales and dolphins and establish marine protected areas, and the ecosystem management approach of the Convention on the Conservation of Antarctic Marine Living Resources. But I know of no one who made conserving marine biodiversity an explicit focus

\section{. . benthic ecology}

has focused far more

on how natural fac-

tors influence the

composition of

seabed communities

than how they are

affected by wide-

spread anthropogenic

disturbances, such as

bottom trawling. 
before Carleton Ray (e.g.. Ray, 1988). In 1989 and 1991. James Broadus brought marine biologists and economists together for two Marine Biological Diversity Working Group meetings at Woods Hole Oceanographic Institution. In 1990, I brought marine systematists. biogeographers. paleontologists. and ecologists together for the Workshop on Marine Biological Diversity at the Smithsonian Institution's National Museum of Natural History, which laid the conceptual foundation for the Global Marine Biological Diversity strategy (Norse. 1993). the marine companion volume of the Global Biodiversity Strategy: Thorne-Miller and Catena (1991) published the first book-length treatment of marine biodiversity, and Butman and Carlton (1995) assembled the first book-length marine biodiversity research agenda. Two rivers of thought had converged.

\section{The Next Major Confluence: Conservation Biology}

Conservation biology is the science of conserving biological diversity. It is multidisciplinary, bringing diverse disciplines-including ecology, demography, biogeography, molecular genetics, reproductive physiology, behavior, epidemiology. ecological economics, ethnobotany, environmental ethics, and law- to bear on conservation questions that resist solution within traditionally defined scientific disciplines. But conservation biology has been a largely terrestrial science. For example, in the leading journal, Conservation Biology, only $5 \%$ of the papers have been marine, compared with $9 \%$ freshwater and $67 \%$ terrestrial (Irish and Norse, 1996).

The conservation biology and the marine biodiversity rivers need to join before the science of marine conservation can progress beyond descriptive assessments and studies of disparate pieces of the picture to address the basic principles of saving life in the sea. A crucial step toward this juncture will occur June 6-9, 1997, when the Marine Conservation Biology Institute and the Society for Conservation Biology will hold the first Symposium on Marine Conservation Biology at SCB's annual meeting in Victoria. British Columbia, Canada.

\section{Other Important Confluences on the Way to the Sea}

Two other important applied streams of thought and action have begun to join the one described above. One is restoration ecology, the science and technology of restoring degraded ecosystems to integrity (e.g.. Thayer. 1992). The other is biodiversity prospecting, the science and technology of finding pharmaceuticals and other useful biochemicals in wild living things (e.g., Reid et al.. 1993).

\footnotetext{
Saving the Sea: An Emotional Call to Arms

In the introductory chapter to the first conservation biology book. Soulé and Wilcox (1980) con-
}

cluded with "An emotional call to arms," that began:

The green mantle of Earth is now being ravaged and pilliged in a frenzy of exploitation by a mushrooming mass of humans and bulldozers. Never in the 500 million years of terrestrial evolution has this mantle we call the biosphere been under such a savage attack. Certainly there have been socalled "crises" of extinction in the past, but the rate of decay of biological diversity during these crises was sluggish compared to the galloping pace of habitat destruction today.

We know more now. We know that the current mass extinction could fall short of the one at the end of the Permian period ( 225 million years ago) by eliminating us before we have eliminated $>90 \%$ of the Earth's species. But there should be little comfort in knowing that our extinction crisis might only be the worst since the end of the Cretaceous (65 million years ago). Our species-not only those other people in other places, but also our leaders, neighbors, co-workers, families, and we, ourselves - are devastating life on Earth.

It is becoming clear that the sea is no more immune to human activities than the land. The world's estuaries have been harmed no less than its rainforests (indeed, mangroves are probably among the most imperiled tropical forests: here, as elsewhere, accurate comparative data are scarce). Marine ecosystems are severely altered near major cities and industrial areas, but the effects of overexploitation of great whales and fishes, of global atmospheric change, and perhaps of pollution from long-lived organochlorines, extend even to the remotest oceanic areas. Our species is just starting to face the enormity of our actions that. cumulatively, are ravaging the blue portion of the Earth no less than its green mantle.

In the last few years, a new marine conservation ethic has emerged. like the flow of a thousand springs from the Earth. that has coalesced into a movement that goes well beyond narrow concern about biomass yields and assimilative capacity to a broader focus on maintaining the sea's biological diversity and integrity. I believe that, swollen by the convergence of the influents described above, the River's flow will raise the sea level of understanding to the point where decision makers will no longer be able to say that they do not know the consequences of their decisions on the sea. Knowing the harm we are causing is not, in itself, sufficient to save the sea, but is an essential basis for guiding the actions. great and small, of humankind's 5.7 billion decision makers.

\section{Acknowledgements}

My six years at the Center for Marine Conservation's marine biological diversity program depended on the generosity of the W. Alton Jones Foundation. the Surdna Foundation, the Educational Foundation of America, the David and $\mathrm{Lu}-$ cile Packard Foundation, the Beneficia Foundation, the Heart of America Fund, the Curtis and 
Edith Munson Foundation, the C.S. Fund. the Marcia Brady Tucker Foundation. the National Oceanic and Atmospheric Administration, the Bay Foundation. Ted Stanley, the Sun Hill Foundation. the Tode Foundation and the Rockefeller Brothers Fund. To these far-seeing friends of the seaweeds. limpets, fishes, and great whales, and to my colleagues and coauthors, I am deeply indebted. This is Marine Conservation Biology Institute Contribution 1 .

\section{References}

Allen, J.M., 1963: The Nature of Bislogical Diversits. McGraw-Hill. New York. $3(14 \mathrm{pp}$.

Butman. C.A. and J.T. Carlton, 1995: Understanding Marine Biodiversity: A Research Agenda for the Nation. Nattional Academy Press. Washington, DC, $114 \mathrm{pp}$.

threnfeld. D. 1978: The Arogance of Hamanism. Oxford University Press. New York, $286 \mathrm{pp}$.

Harper. J.L. and D.L. Hawksworth, 1994: Biodiversity: measurement and estimation. Preface. Phil. Trans. Roy. Soc Lond. B Biol. Sci., 345, 5-12

Hutchinuon, G.E., 1959: Homage to Santa Rosalia, or why are there so many kinds of animals? Amer. Nott. 93. $1.5-159$.

Irish, K.E. and E.A. Norse. 1946: Scant emphasis on marine biodiversity in conservation biology. Conserv. Biol. 10 (in press).

Lovejoy. T., 1980a: Conservation Biology-An EvolutionaryEcological Perspective, Foreword. M.E. Soulé and B.A. Wilcox, eds. Sinauer Associates. Sunderland. MA. 395 pp.

1980h: Changes in biological diversity. In: Council on Envirommental Quality and U.S. Department of State. The Glohal 2006) Repont to the President, wol. 2. The Technicul Report, Washington, DC. 327-332.

MacArthur. R.H. and E.O. Wilson. 1967: The Theory of Islend Biogeengraphy. Princeton University Press. Princeton, $20.3 \mathrm{pp}$.

Myers. N. 1979: The Sinking drk: A New Look at the Problem of Disappearing Species. Pergamon Press, New York. $307 \mathrm{pp}$.

Norse, E.A.. 1992: Biodiversity in marine ecosystems. In World Resources Institute. World Conservation Union \& UN Environment Programme. Global Biodiversity Strategy: World Resources Institute, Washington, DC, 12-13. .ed. 1993: Global Marine Biological Diversity: A Strategy for Building Conservation into Decision Making. Island Press. Washington. DC, $383 \mathrm{pp}$ and R.E. McManus, 1980: Ecology and living resources: Biological diversity. In: Environmental Quality 1980: The Eleventh Annual Report of the Council on Environmental Quality. Washington. DC. $497 \mathrm{pp}$ $31-80$.

K.L. Rosenbaum, D.S. Wilcove, B.A. Wilcox. W.H Rumme. D.W. Johnston and M.L. Stout. 1986: Conserving Biological Diversity in Our National Forests. The Wilderness Society, Washington. DC. $116 \mathrm{pp}$.

Office of Technology Assessment. 1987: Technologies to Maintain Biological Dirersity. Congress of the United States. Office of Technology Assessment. Washington. DC. $334 \mathrm{pp}$.

Ray. G.C. 1988: Ecological diversity in coastal zones and oceans. In: Biodiversity, E.O. Wilson. ed. National Academy Press. Washington. DC, 36-50.

Reid. W.V.. S.A. Laird, C.A. Meyer. R. Gámez, A. Sittenfeld. D.H. Janzen, M.A. Gollin and C. Juma. 1993: Biodiversity Prospecting: Using Genetic Resources for Sustainwhle Develroment. World Resources Institute. Washington. DC, $341 \mathrm{pp}$.

Russell, E.S.. B. Bachman, K. Benirschke, R.W. Briggs. R.H Goodwin. J. Grassle. B.H. Judd. C.F. Lewis. P. Mazur, D.L. Nanney, T.H. Roderick and D.J. Rogers, 1978 Conservation of Germplasm Resources: An Imperative. National Academy of Sciences, Washington, DC, 117 pp.

Soulé, M.E. and B.A. Wilcox. 1980: Conservation biology: Its scope and challenge. In: Conscrvation Biology-An Evolutionar-Ecological Perspectiver. M.E. Soulé and B.A. Wilcox. eds. Sinauer Associates. Sunderland. MA. $1-\mathrm{X}$

Thayer. G.W.. ed.. 1992: Restoring the Nation's Marine Enviromment. Maryland Sea Grant College, College Park. MD, $716 \mathrm{pp}$

Thorne-Miller, B. and J. Catena. 1991: The Living Ocean. Understanding and Protecting Marine Biodiversity Island Press, Washington, DC. $180 \mathrm{pp}$.

U.S. Agency for International Development. 1985: U.S Strategy on the Conservation of Biological Diver sity-An Interagency Task Force Report to Congress. Agency for International Development. Washington. DC. $54 \mathrm{pp}$.

U.S. Department of State. 1982: Procecedings of the U.S. Strat egy Comference om Biological Diversity. November 16-18. 19,81. Department of State. Washington. DC $126 \mathrm{pp}$.

Wilson. E.O.. ed., 1988: Biodiversitv. National Academy Press, Washington, DC, $521 \mathrm{pp}$.

Woodwell. G.M. and H.H. Smith. eds. 1969: Diversity and Stability in Ecological Systems. Brookhaven Symposia in Biology \#22. Brookhaven National Laboratory. Upton. NY. $264 \mathrm{pp}$.

World Resources Institute. World Conservation Union \& UN Environment Programme. 1992: Glohal Biodicersity Strategy. World Resources Institute. Washington. DC. $244 \mathrm{pp}$. 